Revue d'histoire de l'Amérique française

REVUE D.HISTOIRE DE L'AMÉRIQUE FRANÇAISE

\title{
Le Bas-Canada et les imprimés (1809-1810) (suite)
}

\section{Jean-Pierre Wallot}

Volume 21, numéro 2, septembre 1967

URI : https://id.erudit.org/iderudit/302672ar

DOI : https://doi.org/10.7202/302672ar

Aller au sommaire du numéro

Éditeur(s)

Institut d'histoire de l'Amérique française

ISSN

0035-2357 (imprimé)

1492-1383 (numérique)

Découvrir la revue

Citer cet article

Wallot, J.-P. (1967). Le Bas-Canada et les imprimés (1809-1810) (suite). Revue

d'histoire de l'Amérique française, 21(2), 268-280.

https://doi.org/10.7202/302672ar d'utilisation que vous pouvez consulter en ligne.

https://apropos.erudit.org/fr/usagers/politique-dutilisation/ 


\section{LE BAS-CANADA ET LES IMPRIMÉS (1809-1810) (suite)*}

Deux mois ${ }^{1}$ après la parution de la brochure Considérations sur les effets ..., Ross Cuthbert ${ }^{2}$ riposte à Viger dans une brochure anonyme. ${ }^{3}$ Contrairement à ce dernier, qui s'est situé sur le plan des arguments historiques, du ton noble et serein, Cuthbert brocarde fréquemment, invective à l'occasion et adopte en général un ton polémique. Il satirise l'auteur des Considérations: non seulement celui-ci a-t-il pratiqué la démagogie par ses appels à la sensibilité du peuple; il a barbouillé beaucoup de papier pour venger quelques paragraphes inoffensifs d'un journal anglais ${ }^{4}$ que les Canadiens ne peuvent lire (pp. 1-3). En fait, proclame Cuthbert dans un long panégyrique, jamais l'Angleterre n'a tyrannisé les peuples conquis ou cherché à leur inculquer de force sa langue, ses mœurs ou sa religion. Elle n'impose qu'une servitude, la justice pour tous, et obéit aux mêmes principes partout dans son empire: le respect des coutumes locales.

*Voir notre Revue, XX: 556-565; XXI: 81-98.

${ }^{1}$ La Gazette de Québec du 11 mai 1809 et quelques numéros subséquents annoncent la parution et la mise en vente de cette brochure. Prix: 1s. 8d. l'exemplaire.

2 Ross Cuthbert (1776-1861) était le troisième fils de James Cuthbert l'aîné. Il fit une partie de ses études au Collège de Douai, en Flandre. Puis, il hérita de son père les seigneuries de Lanoraie et de Dautray. Admis au barreau du Bas-Canada en 1803, il pratiqua le droit à Québec. Député à l'Assemblée législative du Bas-Canada de 1800 à 1810 , puis de 1812 à 1816 et de nouveau en 1820, il fut également conseiller exécutif de 1812 à 1841 . Mêlé très intimement aux conflits politiques, Cuthbert rédigea trois brochures, dont deux sur la politique: L'Aréopage (Québec, 1803), An Apology for Great Britain... (Québec, 1809). New Theory of the Tides (Québec, 1810) prétendait expliquer le phénomène des marées par l'évaporation de grandes masses d'eau. Cf. Macmillan Dictionary, 168; Dictionnaire général, 1: 457; Bulletin des recherches historiques, 7 (1901): 341-348, et 40 (1934): 627-629.

3 An Apology for Great Britain, in Allusion to a Pamphlet, Intituled "Considerations, \&c. par un Canadien, M.P.P." (Québec, 1809), 30 pp.

4 The Quebec Mercury qui, en fait, prône régulièrement l'assimilation systématique des Canadiens. 
Justice is the basis of British power. Nourished, invigorated and enthroned in this celestial principle, its dominion has spread with the circles of the Globe... Under its sway, people of every colour, every faith, almosi of every language, of widely contrasting habits, manners and customs, proudly acknowledge themselves, protected, ennobled and utterly disenthralled... [4-] Great Britain has never imposed but one servitude on her subjects ... a constant exercice of justice... [5-] Great Britain is the same, on the Thames, the Ganges, and the St. Lawrence. - The great principle of her power, is an indivisible unit: equal justice to all: universal respect to local peculiarities and prejudices: and the Provinces of Canada bear full testimony to the undeviating application of that principle (3-5).

L'état actuel du Canada prouve amplement ce principe. Au lendemain de leur victoire, les conquérants ont cru que la petite population locale - "of such indigence and simplicity"(6) s'assimilerait sans difficulté aux vastes colonies avoisinantes. Encouragés par la générosité de l'Angleterre, les Canadiens se sont plaints des inconvénients du nouveau système de lois dans leurs affaires familiales. Aussitôt, l'Acte de Québec a restauré les lois civiles françaises - sauf dans les townships où les lois anglaises régissent les terres concédées en franc et commun soccage - et transféré les inconvénients sur le dos des colons britanniques. Voilà pourquoi, en 1791, la mère patrie a scindé la colonie en deux: ainsi, elle dotait les Canadiens, dans le Bas-Canada, du moyen législatif de perpétuer leurs lois, leurs coutumes et leur langue, malgré les inconvénients de cette politique dans une colonie en expansion. Et jusqu'ici, la majorité a frustré toute tentative d'innovation et rembarre même toute idée de réforme:

... Thus [by the Quebec Act] the primitive colony was restored entirely to itself and all its fractured parts nicely reunited; and perhaps, as appears by daily indications, more firmly jointed than before. The cession of the country seemed a vision. But the inconveniences ... . were merely removed from the new to the old subjects...: on entering Cana- 
da, they entered a labyrinte ... [7-] [In 1791, beside the gift of an Assembly] The Colony is divided into two Provinces; so that the original Canadian population, might remain entire, uninvaded, and in the full possession of every avenue to a branch of the Provincial Legislature! Thus did the mother country, prove its own good faith, and ... constitute them [the Canadians] the defenders of their ancient, and disposers of their future laws; the judges of their own wants; masters of their own revenue...; in fine, thus conferred all the benefits of a perfect Legislative establishment, without the cares, responsibility or perils of Empire! It is thus, indeed that Great Britain has taken every means in her power! What! to modify or change the ancient laws, customs and language of the Canadian people? No! rather to perpetuate them all, however great, the evil, inconvenience, and thraldom they may inflict and impose on a growing country.

... If ... attempts are made [to change the laws in the legislature], failure is uniform: and the country is left without a subsequent remedy (6-7).

Or, les lois françaises, nées dans des temps obscurs, brillent plutôt par leur complexité et leurs bizarreries que par leur clarté. ${ }^{5}$ Elles ressemblent à un labyrinthe où la justice et les crimes jouent " à la cachette". Telles quelles, elles ligotent le commerce: v.g. le droit lignager, les lods et ventes, etc. Malgré l'excellence des principes de base, il faut modifier la superstructure.

Quant à la langue, "The British people have never made war upon sounds": il se fiche bien de la langue employée par les Canadiens "in their tender vigils" (9). Même en Angleterre,

5 Dès 1803 , dans L'Aréopage, Cuthbert avait découpé déjà une arêto importante de sa pensée relativement aux lois canadiennes. Les lois francaises, y écrivait-il, sont poussiéreuses, antiques. Or, les avocats les ont déformées et exploitent une jurisprudence contradictoire. Dans la colonie coexistent ou se chevauchent les lois criminelles anglaises, le droit commun de la France, la coutume de Paris et celle d'Orléans, les lois commerciales anglaises de même que celles relatives aux offenses personnelles, les édits, ordonnances et statuts depuis les débuts, le tout dans deux langues et avec une prolifération d'interprétations variées, voire contradictoires. Le gouvernement devrait profiter de la paix - à ce moment, la paix d'Amiens - et de la jeunesse de la colonie, pour réformer le système judiciaire et uniformiser les lois. 
les gens cultivés se piquent de connaître le français. Dans la colonie, on baragouine partout dans un mauvais patois. Le français s'étale au même titre que l'anglais dans les cours de justice, à la législature, dans les statuts provinciaux et les avis publics. Les Britanniques et leurs enfants parlent les deux langues. Heureusement, les Canadiens des villes s'efforcent avec succès d'apprendre l'anglais.

Voilà pour les lois et la langue, deux des trois principaux points abordés par les Considérations... D'autre part, la largeur de vues des Britanniques et des lois positives (capitulations, traité de paix de 1763, l'Acte de Québec, l'Acte constitutionnel) garantissent le libre exercice du culte catholique. D'ailleurs, les religions catholique et protestante ne sont-elles pas sœurs? En forçant les catholiques canadiens à payer leurs dîmes, l'Angleterre les empêche en fait de délaisser la pratique, à cause de leur avarice, et de se vouer de plus en plus à une religion de contacts directs, personnels et moins coûteux avec Dieu. Elle est donc devenue "the liberal PATRON of the Catholic Church in this Province" (13). Les Britanniques de la colonie respectent les convictions des catholiques. Ils évitent de troubler leurs processions et autres manifestations extérieures de leur culte. Le clergé lui-même a su reconnaître l'appui magnanime du gouvernement. Par conséquent, "it has not only been the policy, but the distinctly pronounced, and unequivocally proven, determination, of the British Government, and people, to sustain the Canadians, in the entire enjoyment, of the religion, laws and customs of their forefathers" (14).

L'auteur des Considérations... a brandi des précédents historiques pour détourner les Britanniques de toute idée de changement: exemples qui convient mal aux conclusions qu'il en a tirées: au moment de leur conquête, l'Angleterre, la Belgique et la Sicile étaient des pays complètement habités et cultivés, avec des lois et des coutumes cristallisées depuis des siècles, donc des pays constitués et parvenus à leur maturité.

But the Province of Lowe-Canada, politically considered, is in the first stage of infancy. The eagle in its passage across, sees nothing, but one intermin- 
able forest, save, a blue net-work of rivers, and a narrow strip of cultivation, which borders the St. Lawrence. The occupied portion is to the unoccupied nearly, as 1 to 50, or in such other ratio, as makes the Province, socially, as a whole, in a condition perfectly rude and maleable; and capable of receiving any impressions, it might be desirable to imprint. It is a bust, on which the sculptor, has finished a single feature only, leaving all the others still to be formed * (15).

* Shall the original design, be strictly followed, as our author requires, [16-] and the remaining feautres, be made to harmonize with the first ? Or leaving this, entire, and undeteriorated, shall a different model be copied, in the accomplishment of the rest? In plain terms, shall the 49 unoccupied parts of this Province, be filled up and completed, on the same plan, that the one fiftieth part is already established; or ought a more eligible system to be pursued ? (15-16).

Le Bas-Canada, dans l'empire, ne représente qu'un centième de la population $(250,000$ contre $25,000,000$ - y compris les colonies d'Orient). Et si l'on ajoute à ces chiffres le degré de civilisation plus avancé et les capitaux de sa portion européenne, on devrait plutôt dire 1/500ième. Aussi, après la Conquête, n'y aurait-il eu rien de cruel ni de dangereux à métamorphoser le caractère du peuple canadien, si la raison d'Etat l'avait exigé.

If it had been, desirable to draw inferences, from correct resemblances, they should have been sought for in the vicissitudes of those states, which, when in an incipient, fugitive, or incompacted condition, admitted of facilities to change ... The history of the early stages of society in the eastern continents, abounds with such instances: then, nothing was fixed, or permanent, in the order of things: and the characteristics of the conquered soon merged into those of the conquerors (17).

Ainsi, les Hollandais du New York se sont fondus dans leurs conquérants: bien traités, ils n'ont jamais tenté d'imposer leurs lois et leurs coutumes au souverain et à ses sujets. En hommes 
sages, ils ont plutôt collaboré à l'introduction des lois et de la langue anglaises. "The two people gradually assimilated; until the original distinctive marks totally disappeared, in one uniform British mould." Il n'y eut pas de conflits de races (19). La population de la Nouvelle-Orléans (de souches française, espagnole et américaine) deviendra graduellement homogène. Il s'agit là d'un phénomène naturel, qui aurait joué également dans la province, "had not a stern, active, and ungrateful resistance been made, to the admission of whatever savoured of the British Nation" (20).

Depuis la Conquête, les Canadiens se sont efforcés de s'immuniser contre toute contamination britannique. Ils se sont palissadés derrière un autre "mur de Chine", i.e. derrière leur particularisme. De sorte qu'on se croirait encore en France, surtout dans les campagnes, à cause de la langue, des coutumes, de la manière même de recevoir.

... On entering a house french civility, french address, french vesture, would meet his [the visitor's] eye. In one of the best french dialects, he would hear, of savon français, soulier français; and every thing else, that it might be desirable to distinguish, he would find elevated, by the adjective, français. Should one of the tender shoots, of the family, attune her voice, he would probably hear the pretty pastoral, of, "Sur les bords de la Seine", or some other stanzas, that would convey him to the delectable vales of old France. On surveying the "chambre de compagnie", among many other saints he would see the portrait of Napoleon//. In short he would never imagine, he was passing over the skirts of the British empire.

// It is a fact, the pretended portrait of that fiend, may be found in many country houses: sometimes alone; sometimes reviewing his consular guards. There is a fine one, in high preservation, at the upper post-house of Carouge. It cannot be supposed these portraits are procured as a mere historical memento (20).

Cette persévérance têtue dans les vieilles coutumes n'a rien de répréhensible en soi: à condition qu'elles n'handicapent pas 
l'ensemble de la société. Malheureusement, certains individus tentent de former une nation canadienne:

... This tenacity, of whatever tends to preserve the perfect integrity of their cast, does not proceed, merely from habit, but is in some degree regulated on principle: such little inoffensive partialities, are systematically constituted, the out works of the Religion and political consequence of the Canadians: those must stand firm there, who mean that the citadel shall not be approached.

It is certain there is in this Province a few individuals, actuated by different motives, who unite their endeavors to form the Canadian people, properly so called into a body politic: to condense it, to a vast, homogeneous, impenetrable, volume, that time, will rather tend to strengthen than impair. They seem already to have organized their plan extensively, and minutely, in the false hope of rendering it imperishable (21).

Plusieurs mobiles les animent: la crainte de la protestantisation après l'assimilation; le désir de s'attirer le respect et l'attention du gouvernement et du peuple britanniques par une action ferme et commune, donc plus efficace; la possibilité, pour les démagogues, de s'agiter et d'arracher ainsi des places au gouvernement; l'amour des ancêtres. $\mathrm{Au}$ fond, la méfiance, due à l'ignorance, sécrète ces attitudes. Car malgré leurs grandes qualités - respectabilité, honorabilité, bonne foi, franchise, loyauté, "proud submission... dignified obedience... subordination of the soul" - les Canadiens sont victimes d'une ignorance et d'une susceptibilité extrêmes. "... [They] form a rich soil for our half fledged political quacks" (22).

Leur volonté de survie en tant que collectivité distincte est vouée à l'échec: "... their body politick will dissolve ... in the purity and brightness of the british character. The prejudices and useless peculiarities of the Canadians, will melt away like a vapour, in a summer's dawn." Non à cause d'une politique de force, mais d'un processus naturel, chimique, d'intégration "in the effervescence of a British menstruum" (22). Rien n'y pour- 
ra résister. Préfigurant Durham, Cuthbert, qui déjà immole la "tolérance britannique" qu'il a tant vantée au début, se demande comment les Canadiens pourraient d'ailleurs justifier leur désir de survie.

The population of this Province forms a small compact body inert in its nature, without one principle of percussion; and exhibiting its infant face, surcharged with all the indications of old age and decay. During a lapse of two centuries, little more than the borders of the St. Lawrence have been put under cultivation; in a few places only, have settlements slumbered forth, on the minor [23-] streams, with manifest reluctance and regret. Frequently a family groups together, until the original farm is divided into ribbons of land, and one extremity grows to a village. When necessity forces a younger branch, to form a new establishment, he does not pierce the recesses of the forest, in quest of a spot, equally fortunate in its soil and position: he makes no enquiries that may bring within his reach, a choice of objects: he will fix his eye on the steeple of his paternal church, and mark and adopt the piece of land, that may be at the least possible distance from that second centre of gravity; it is no matter, whether his lot falls on marsh, rock, or sand; ... Thus have our Canadian settlements, insensibly gnawed out a few niches in the primitive woods of this country; and thus by a system of close adhesion, have the limits of cultivation been kept contracted, and its modes, in many points defective, perpetuated $(22-23) .^{\circ}$

- Cette critique de l'immobilisme canadien n'est qu'un élément qui s'imbrique dans l'argumentation générale en faveur de l'assimilation (voir plus loin). Dans son analyse de la brochure et de divers articles du Mercury, D. G. Creighton a éliminé tous les passages où l'on prône l'assimilation, où l'on malmène les lois, la langue, la religion, l'éducation et les mours des Canadiens, pour ne citer que ceux où l'on s'en prend à leur conservatisme. De la sorte, il peut conclure que les Britanniques n'ont jamais mis en question sérieusement les lois, la langue, les coutumes et la religion des Canadiens, bref leur nationalité; que les antinomies dans le Bas-Canada se limitaient à des affrontements sociaux et économiques: agriculture vs commerce; féodalité vs capitalisme; "philosophie" paysanne, conservatrice et catholique des Canadiens vs le dynamisme commercial, anglais et protestant des Britanniques; etc. Cf. Commereial Empire of the St. Lawrence (Toronto, 1937), 159 ss. 
Faut-il alors se surprendre qu'un autre peuple plus entreprenant s'attaque à l'immense partie sauvage et inexploitée du pays?

And is it then surprising, when nature seems in vain to have unfolded to our view, one of her grandest panorama's; combining every soil, rich by centuries of repose; ... that a more active population, that the prying intrepid American, should appropriate what we refuse? Can we, immovable, and inadventurous, lament... that while we sleep on the bright lap of our country, her bosom should be rifled of every fair jewel by a foreign intruder? The fault is in us ... (23).

Si les Canadiens avaient osé se disperser dans les forêts, les établissements, moins concentrés, seraient plus nombreux et plus riches, les Canadiens, plus instruits. Quelle que soit la moralité des Américains, les forêts s'éclaircissent devant leur énergie. "Where we trace a road they will carve a canal; where we erect one bridge they will raise 20 . While one of our establishments attains the elevation of a dram shop, the will have built and embellished a town." (24) Sur le plan politique, les Américains émigrent ici parce qu'ils sont dégoûtés des dissensions continuelles qui fermentent aux États-Unis. Ils trouvent enfin la vraie liberté, sous un bon gouvernement paternel, l'absence de taxes et de persécution. Et puis, le travail continuel purifie les mœurs. De sorte que les Américains perdront peu à peu leurs mauvaises habitudes et s'attacheront au pays où ils prospèrent. Leurs sentiments politiques deviendront entièrement britanniques. D'ailleurs, beaucoup d'entre eux ont conservé leur attachement à leurs origines, particulièrement en Nouvelle-Angleterre d'où viennent les imigrants. Ce sont les journaux à la solde du gouvernement des Etats-Unis qui entretiennent chez les Américains une prétendue haine de l'Angleterre. Enfin, on a admis surtout des loyalistes.

Bien qu'on ne forcera jamais les Canadiens à s'angliciser - et il n'est pas question de les protestantiser -, il est incontestable que l'assimilation entraînerait d'heureuses conséquences. L'homogénéité renforce les liens qui unissent les hommes, selon 
le principe universel de l'amour de soi et de ceux qui nous ressemblent. D'une fusion plus intime des groupes, il résulte une force accrue. Tant que les Canadiens ne s'identifieront pas aux Britanniques, ils se sentiront étrangers dans leur pays. D'autre part, cette province recevra une grande population britannique: Anglais, Écossais et Irlandais qui la feront progresser rapidement grâce à leur industrie et à leur technique supérieures. Leur nombre croîtra. Ils constitueront un groupe national estampillé des traits de la Grande-Bretagne et tirant d'elle sa vigueur et sa permanence. Cette racine vigoureuse et en pleine croissance va-t-elle se plier à la petite plante chétive locale? Que les Canadiens s'amalgament donc dans ce nouveau peuple qui grandit dans la province!

However certain it is that neither force, deception, or persuasion, will ever be employed to anglify the Canadians, in so far as relates to their language, habits and customs; (for their religion is totally out of the question) it is superlatively absurd and indeed most ridiculous, to pretend that the actual dissimilarity, prevailing in this country, constitutes the best defence of a british Province! Among men, ressemblance is union. A person will always prefer another, of his own opinions, habits, language, colour or even name, to such as may differ in these points of relation. Similar sentiments and feelings, create a common sympathy among the persons possessing them; and sympathy is the basis of all affections ... [28-] we involuntarily associate with those, in whom, from a similitude of feeling and manner, we seem to discover our own image. These tendencies, originate in the universal and indestructible principle of self-love... And as every point of resemblance among the individuals who compose a State is a bond of union, the greatest uniformity, will necessarily produce the greatest degree of national strength.

On the contrary every point of difference, is also one of repulsion: and this issues from the same principle of self love; for we involuntarily turn with indifference and sometimes disgust, from qualities and characteristics in others, which instead 
of concurring, are brought in comparison or competition, with our own.

So long as the Canadians continue to form a contrast, with their English fellow subjects, in so many particulars, they will continue to feel as strangers. They may respect, they may esteem, but it is difficult to suppose, they can possess that unison of sentiment, which constitutes equally the charm and the strength of society. They who believe the reverse must deal in levities... It might as well as expected a stage coach would be better drawn by a combination of horses and hyaenas, than by a uniform team of the former alone...

[29-] This Province is destined to receive a large british population. English, Irish, Scotch particularly from the Highlands, and American Loyalists, are emigrating to our rising country. They find it a virgin waste, untouched by human industry or art, except the narrow selvage we occupy. Under the exercise of superior labour, skill and enterprize, their means and number will take a rapid growth. They will form a widely encreasing body, bearing all the national traits of Great Britain, and deriving from the mother country, qualities to which a constant intercourse with her will give depth, vigor and permanency. The impossibility of preserving a state of Society perfectly homogeneous in this Province, appears absolute. Among the Canadians another people are forming, who have all the characteristics of the parent state. Would it be more expedient, that they should shed their national marks and adopt those of the Canadians? or would it be more reasonable and politic, in these, to recede with less reluctance from those useless peculiarities which, without conferring any advantage, constitute so many points of repulsion? The question conveys its own answer. The british Oak has shot across the ocean his mighty root; he has broken through every stratum of the earth: and it would be more wise in the gentle Lilac her, to intermix her fibres in friendly confidence, than to resists in vain the herculean ramification. ${ }^{\text {? }}$

7 Paragraphes qui prouvent parmi bien d'autres textes, que les Britanniques ont aussi une conscience collective très développée et des ambitions "nationales". 
Happy respectable Canadians, listen with caution, to perhaps your well meaning sooth-sayers: survey for yourselves the fair eminence on which you repose. The first Nation of our Globe: first in her attainments of civil and political liberty; first in moral sentiment and the unalterable exercice of justice, calls you to the proud condition of british subjects. She invokes the development of your genius, your talents and industry; and has opened all the avenues to individual prosperity. Let fifty years of good [30-] faith, beneficence and paternal care, chace from your mind the last traces of distrust. Calculate your own experience; sum up the acts, qualities and propensities of the British Government and people, and frankly say, whether the result ought not to procure for them, your respect, esteem and reliance? Then, united and ennobled by our distinguished political fate, let us promote without guile the peace and welfare of our portion of the Empire: let us freely mix and incorporate with a Nation which has conferred on us her good fortune, and her lustre; a nation on whose domain the Sun never ceases to shine, and whose glory will encrease with the bounds of memory $(27-30)$.

La péroraison triomphale n'émeut guère Le Canadien. "Sacros-Picos", au contraire, daube le pamphlétaire. Celui-ci - "Oh la belle conception!" - ose affirmer que les Américains nourrissent une tendre affection à l'endroit de l'Angleterre et du roi!

... On prend à tâche de faire l'apologie des Américains, sous prétexte de faire celle de la Grande-Bretagne; aussi vient-on nous dire que le différend qu'ils ont disputé à main armée, dans lequel ils ont eu raison à la pointe de l'épée n'était qu'une dispute sur des points constitutionnels, sur lesquels ... on a pris des arrangements de famille... Il reste cependant une petite difficulté à éclaircir. Les honnêtes Américains qui firent cet arrangement de si bonne grâce, à main armée et au bruit du canon, pourraient avoir quelque jour la même fantaisie, s'il était possible qu'ils pussent acquérir, dans ce pays, une prépondérance assez marquée pour faire goûter 
leurs opinions. Je laisse à penser quel pourrait être l'effet d'une discussion constitutionnelle, soutenue avec les mêmes arguments!

Le journal accuse également l'auteur de la brochure d'avoir ignoré ou escamoté les exemples cités dans les Considérations... pour en invoquer d'autres (v.g. Les Hollandais du New York) sans relations avec le Bas-Canada.

Nous ne doutons point que quelques-uns de ces penseurs ne fussent flattés de voir les Canadiens éprouver le sort des Espagnols de la Jamaïque, dont on ne parle que comme d'une chose qui fut autrefois ... Quant à la province de New-York, cet admirable exemple est à envier... mais... Il aurait fallu nous dire qu'il put être imité ici ... sans bouleverser le pays... [et] tout perdre. Il aurait fallu nous dire en outre... quel rapport il y a entre une province enclavée dans les colonies, Anglaises à cette époque, et dans la situation politique et géographique à celle où nous nous trouvons aujourd'hui ...

Quant au défrichement du pays, que penserait de l'“Apologiste" un voyageur qui parcourrait la province de "Cap-Mouraska" jusqu'à Pointe-au-Baudet! Le titre même de la brochure est "insidieux" et "perfide". En réalité, l'apologie de la GrandeBretagne, il faut la chercher dans les Considérations ....8

$$
\text { (à suivre) }
$$

JEAN-PIERRE WALLOT

Musée national

8 Le Canadien, 13 mai 1809. 